\title{
OBSERVATIONS DURING EMBRYONIC DEVELOPMENT IN THE GENUS DOTO (GASTROPODA, OPISTHOBRANCHIA)
}

\author{
By ANNETRUDI KRESS \\ Department of Anatomy, University of Basle, Switzerland
}

(Plates I-III and Text-figs. 1-2)

\begin{abstract}
Data on egg diameter, capsule size during embryonic development and veliger size have been compared in the three species $D$. coronata, $D$. pinnatifida and $D$. fragilis. It became clear that there are distinct specific differences in these features as well as in the time of development. Certain ratios, however - i.e. between capsule length and width at different stages, capsule volume/egg volume and the degree of egg capsule enlargement - are very similar, if not identical. The same holds true for the veliger shells, which are distinctly different in size but very similar in proportions. Some tests have been performed to check the influence of salinity, especially on the behaviour of the egg capsule. The salinity tolerance proved to be extremely limited for the embryos; the capsules, however, showed no change compared with those maintained under normal conditions if the embryo itself remained healthy.
\end{abstract}

\section{INTRODUCTION}

While working on taxonomic problems in the family Dotoidae and comparing the Mediterranean and Atlantic species (Schmekel \& Kress, in the Press), it became apparent that very little embryological information was available for this group, other than that published by Alder \& Hancock (1845-55), Pelseneer (1911), Miller (1958, Ph.D. Thesis, University of Liverpool) and Thompson (1967).

In the course of studies on the changes in egg-capsule volume in different nudibranch species (Kress, 1971, 1972) a fresh attempt has been made to obtain some comparative data on egg and capsule sizes and on the course and rate of embryonic development in the three species of Doto most commonly found in the Plymouth area, namely $D$. coronata (Gmelin, 1791), D. pinnatifida (Montagu, 1804) and D. fragilis (Forbes, 1838).

\section{MATERIAL AND METHOD}

This study is based on material collected in the Plymouth area (England) during August and September 1971 and July to September 1974.

Spawn from the three species was either brought in with the animal concerned and the hydroids on which it had been laid, or more frequently was that laid down by animals held in individual glass bowls. The spawns were kept in glass jars in the cold room $\left(10-12{ }^{\circ} \mathrm{C}\right)$ or at room temperature $\left(18-22^{\circ} \mathrm{C}\right)$ with changes of filtered sea water every other day. Every day a portion of each spawn was examined, measurements being made of the capsules' long and short axes. The volume of the capsules was calculated according to the rotation-ellipsoid formula described in earlier papers (Kress, 1971, 1972). Differences in development within a single spawn were marked, especially during advanced development, although it should be noted that only capsules containing veligers of comparable stages were measured. The ratio between capsule volume at hatching and the eggcapsule volume itself has been entitled the 'enlargement factor'. Not all the veligers within a 
spawn hatch at the same time - this is especially noticeable in the larger spawns of $D$. fragilis and D. pinnatifida. Hatching was stated to have taken place on the day when the majority of veligers were observed to be free of their capsules.

\section{RESULTS}

General observations concerning the embryonic development

In all three species oviposition occurs most usually during the night or in the early morning.

Members of the genus Doto belong to the development-Type I, a species with small eggs and planktotrophic larvae (Thompson, 1967). Certain features of embryonic development can be followed in the intact capsule. Some stages have been defined according to changes of the exterior morphology and used as pointers for grouping. The

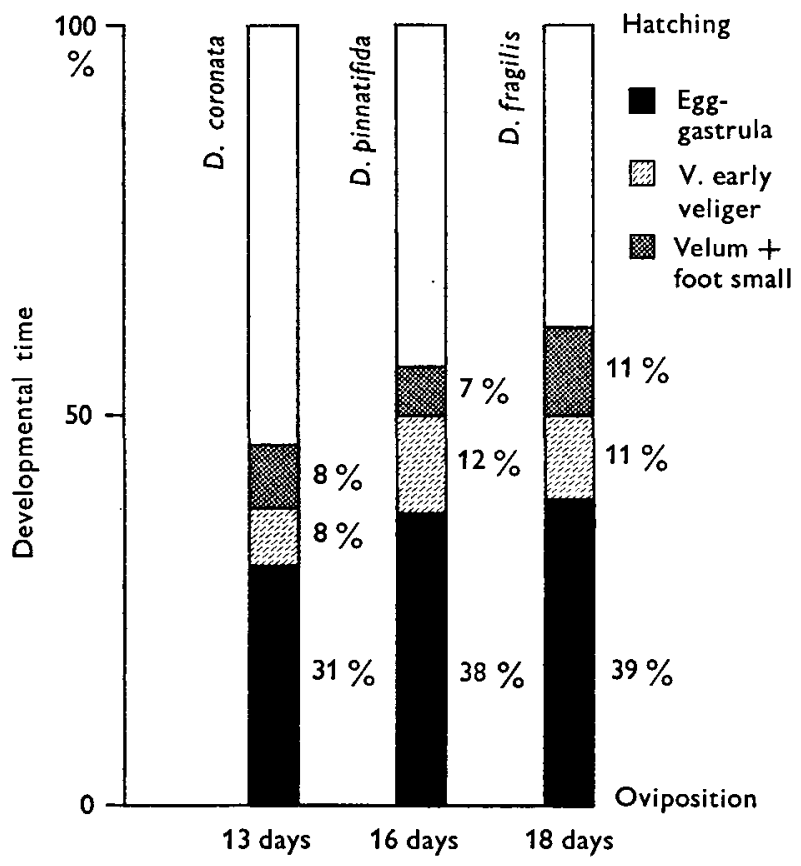

Text-fig. 1. Comparison of time intervals necessary to complete gastrulation and early stages of veliger growth.

sequence of observable embryonic events appears similar in each of the three species investigated, only the time-course of the events proving somewhat variable (Text-fig. 1). If the number of days between oviposition and hatching is taken as $100 \%$, Doto coronata needs 4 days ( $=31 \%$ of the whole development) to complete gastrulation, while $D$. pinnatifida takes 6 days $(38 \%)$ and $D$. fragilis 7 days $(39 \%)$.

After gastrulation the embryo assumes a more ovoid shape and the apical area becomes ciliated (Pl. II H and I). Later the first signs of foot and velum appear. This stage was called 'very early veliger' (P1. IIIA) and the period it lasted varied somewhat in the three species. When foot and velum are more distinct, the embryo is classified as 'small' 
(Pl. III B). Different time intervals appear to be necessary within the three species before this shape is attained. At this stage the embryo starts to rotate. The typical veliger form is then rapidly assumed. It would be arbitrary to separate more definite stages within the development on the basis of one daily measurement only.

The capsule membrane becomes softened at hatching time. The veliger distorts the capsule by the beating movement of its cilia along the wall.

\section{Doto coronata}

The spawning animals were Doto coronata with no red marks at the base of the inner side of the cerata (cf. Schmekel \& Kress, in the Press). They were between 6 and $11 \mathrm{~mm}$ long (Pl. IA). The spawn was found mostly on Nemertesia antennularia, a few on Obelia geniculata. It consists of a gelatinous colourless ribbon folded in a zig-zag manner, measuring $1-3 \mathrm{~mm}$ in width and up to $10 \mathrm{~mm}$ in length (P1. II A); the eggs themselves are white. In all, 18 spawns were used to obtain measurements. Three were measured from oviposition to hatching and another 15 from blastula stage to hatching or to intermediate stages of development. The egg capsules have a smooth surface and contain one egg per capsule. Twins could occasionally be detected in some of the spawns. The average egg diameter is $72 \cdot 5 \mu \mathrm{m}(62 \cdot 4-81 \cdot 6)$.

As a rule 1-3 polar bodies were visible, oval or round in shape and with a diameter of $4 \cdot 8-7 \cdot 2 \mu \mathrm{m}$. These could be seen until very shortly before hatching. At $10-12^{\circ} \mathrm{C}$ the developmental period was 13 days, at room temperature $\left(18-22{ }^{\circ} \mathrm{C}\right) 7-8$ days.

\section{Changes in capsular size and volume (Table 1)}

The ratio between the egg-capsule volume and the egg volume itself was $1 \cdot 9(1 \cdot 6-3 \cdot 0)$. The capsule volume showed no increase until the earliest signs of veliger development, and the first appearances of minute velar cilia. Differences in volume measurements up to that stage are due to differences within the spawn itself. As the veliger grows there is an increase in capsule volume. When the veliger shows its first distinct characteristics the capsule still fits closely to it, but from this point on the capsule obviously increases faster than the veliger and this allows more space for a free and active rotation of the veliger.

The ratio between the hatching volume of the capsule and the egg-capsule volume was entitled the 'enlargement factor', the average for $D$. coronata being $3.5(3 \cdot 1-4 \cdot 0)$. The ratio between the capsule length and width at the onset of development was 1.3 at hatching $1 \cdot 1$, the capsules becoming more spherical in shape (PI. IIID). The newly hatched veliger is type I (Thompson, 1961) the shell measuring $116 \mu \mathrm{m}(100.8-124.8)$ in length, $95 \mu \mathrm{m}(86 \cdot 4-100 \cdot 8)$ in width and $95 \mu \mathrm{m}(86 \cdot 4-100 \cdot 8)$ in height (Pl. III E).

\section{Comment}

The spawn of Doto coronata has been pictured by Alder \& Hancock (1854-5) and by Larsen (1925), and described by Løyning (1927). Our measurements of egg diameter $(68-73 \mu \mathrm{m})$ accord with Miller's data (1958) and with those of Thompson (1967) (61-67 $\mu \mathrm{m})$. One of the spawns examined contained eggs of an exceptionally large diameter, $76-81.6 \mu \mathrm{m}$, which therefore increased the average measurement. On the other hand, Schmekel gives $75 \mu \mathrm{m}$ as a mean value for the Mediterranean $D$. coronata 

TABLE 1. DOTO CORONATA: MEAN VALUES OF EGG AND CAPSULE
SIZES AND VOLUMES

\begin{tabular}{|c|c|c|c|}
\hline Stage & $\begin{array}{l}\text { Mean value } \\
(\mu \mathrm{m})\end{array}$ & $\begin{array}{l}\text { Standard } \\
\text { deviation }\end{array}$ & $\begin{array}{c}\text { Ratio } \\
\text { between }\end{array}$ \\
\hline Egg diameter & $72 \cdot 5$ & $6 \cdot 8$ & \\
\hline \multicolumn{4}{|l|}{ Capsule size } \\
\hline $\begin{array}{l}\text { Egg to gastrula stage } \\
\text { Length } \\
\text { Width }\end{array}$ & $\begin{array}{r}103 \\
82\end{array}$ & $\begin{array}{l}6 \cdot 3 \\
6 \cdot 7\end{array}$ & Length and width: $1 \cdot 3$ \\
\hline $\begin{array}{l}\text { Hatching } \\
\text { Length } \\
\text { Width }\end{array}$ & $\begin{array}{l}142 \\
131\end{array}$ & $\begin{array}{l}8 \cdot 2 \\
9 \cdot 5\end{array}$ & Length and width: $\mathbf{1} \cdot 1$ \\
\hline $\begin{array}{l}\text { Veliger shell } \\
\text { Length } \\
\text { Width } \\
\text { Height }\end{array}$ & $\begin{array}{r}116 \\
95 \\
95\end{array}$ & $\begin{array}{l}4 \cdot 6 \\
4 \cdot 2 \\
4 \cdot 2\end{array}$ & $\begin{array}{l}\text { Veliger shell length and } \\
\text { egg diameter: } 1.6\end{array}$ \\
\hline & $\begin{array}{c}\text { Volume } \\
\left(\mu \mathrm{m}^{3} \times 10^{3}\right)\end{array}$ & & \\
\hline Egg & 198 & $58 \cdot 6$ & $\begin{array}{l}\text { Egg-capsule volume and } \\
\text { egg volume: } 1.9\end{array}$ \\
\hline \multicolumn{4}{|l|}{ Capsule containing } \\
\hline $\left.\begin{array}{l}\text { Blastulae } \\
\text { Gastrulae }\end{array}\right\}$ & 379 & $72 \cdot 5$ & \\
\hline \multicolumn{4}{|l|}{$\begin{array}{l}\text { Capsule containing } \\
\text { veliger }\end{array}$} \\
\hline Very early & 379 & $50 \cdot 4$ & \\
\hline Foot and velum small & 451 & $64 \cdot 1$ & \\
\hline Foot and velum medium & 532 & $52 \cdot 9$ & \\
\hline Foot and velum distinct & 647 & $91 \cdot 5$ & \\
\hline $\begin{array}{l}\text { Foot and velum distinct } \\
1 \text { day before hatching }\end{array}$ & $\begin{array}{l}753 \\
814\end{array}$ & $\begin{array}{l}187.9 \\
156.6\end{array}$ & \\
\hline 2 days before hatching & 1109 & $189 \cdot 7$ & \\
\hline Hatching & 1312 & 270.8 & $\begin{array}{l}\text { Capsule volume at hatching } \\
\text { and egg-capsule volume: } \\
3.5\end{array}$ \\
\hline
\end{tabular}

(personal communication). The occasional occurrence of twins is mentioned in Pelseneer (1911) and Miller (1958) and this also accords with our observations. The colour of the spawn observed was white in every instance but Miller (1958) records some of a pink colour. The developmental time given by Thompson (1967) is 16 days at $10^{\circ} \mathrm{C}$. In our case all three species were kept in a cold room with slightly varying temperature between 10 and $12{ }^{\circ} \mathrm{C}$, a fact which would account for the somewhat faster development (13 days). Hadfield (1963) mentioned 7 days at $10^{\circ} \mathrm{C}$, and this makes it very doubtful that he really dealt with $D$. coronata at all.

\section{Doto pinnatifida}

All the animals concerned correspond to the description given by Schmekel \& Kress (in the Press) (Pl. IB). The spawn was obtained from large animals, from 17 to $22 \mathrm{~mm}$ in length. Spawns used were found in the Plymouth area on Nemertesia antennularia together with the animals concerned, or were those laid down by animals held in glass jars in the laboratory. The spawn consists of a strongly undulated ribbon measuring up 
to $35 \mathrm{~mm}$ in length (unstraightened), the ribbon itself being $3-5 \mathrm{~mm}$ in width (P1. II B). The eggs are pink or white. The same animal is capable of producing a spawn of either colour.

\section{TABLE 2. DOTO PINNATIFIDA: MEAN VALUES OF EGG AND CAPSULE SIZES AND VOLUMES}

\begin{tabular}{|c|c|c|}
\hline Stage & $\begin{array}{l}\text { Mean value } \\
\quad(\mu \mathrm{m})\end{array}$ & $\begin{array}{l}\text { Standar } \\
\text { deviatior }\end{array}$ \\
\hline Egg diameter & $95 \cdot 5$ & $4 \cdot 2$ \\
\hline Capsule size & & \\
\hline $\begin{array}{l}\text { Egg to gastrula stage } \\
\text { Length } \\
\text { Width }\end{array}$ & $\begin{array}{l}140 \\
113\end{array}$ & $\begin{array}{r}11 \cdot 20 \\
5.8\end{array}$ \\
\hline $\begin{array}{c}\text { Hatching } \\
\text { Length } \\
\text { Width }\end{array}$ & $\begin{array}{l}192 \\
175\end{array}$ & $\begin{array}{l}18 \cdot 5 \\
10 \cdot 6\end{array}$ \\
\hline $\begin{array}{l}\text { Veliger shell } \\
\text { Length } \\
\text { Width } \\
\text { Height }\end{array}$ & $\begin{array}{c}160 \\
124 \\
123 \\
\text { Volume } \\
\left(\mu \mathrm{m}^{6} \times 10^{3}\right)\end{array}$ & $\begin{array}{r}10 \cdot 8 \\
6.6 \\
8 \cdot 9\end{array}$ \\
\hline Egg & 455 & $62 \cdot 4$ \\
\hline $\left.\begin{array}{l}\text { Capsules containing } \\
\text { Eggs } \\
\text { Blastulae } \\
\text { Gastrulae }\end{array}\right\}$ & 937 & $140 \cdot 9$ \\
\hline $\begin{array}{l}\text { Capsules containing } \\
\text { veligers }\end{array}$ & & \\
\hline $\begin{array}{l}\text { Very early } \\
\text { Foot and velum small }\end{array}$ & $\begin{array}{r}938 \\
1047\end{array}$ & $\begin{array}{r}147 \cdot 0 \\
92 \cdot 6\end{array}$ \\
\hline Foot and velum medium & 1178 & $70 \cdot 9$ \\
\hline Foot and velum distinct & 1466 & $138 \cdot 6$ \\
\hline Foot and velum distinct & 1758 & $140 \cdot 3$ \\
\hline 2 days before hatching & 2494 & $239 \cdot 4$ \\
\hline 1 day before hatching & 2742 & 323.8 \\
\hline Hatching & 3202 & $724 \cdot 1$ \\
\hline
\end{tabular}

Capsule volume at hatching and egg-capsule volume: $3 \cdot 4$

In all twelve spawns were measured, two from oviposition to hatching, the remaining ten for different lengths of time during the developmental process. The egg capsules have a smooth surface and normally contain one egg per capsule, although pairs of twins can now and again be observed. A few empty cases of variable shape are mostly found at each end of the ribbon. The average egg diameter is $95.5 \mu \mathrm{m}$ (91-108). Usually 1-3 polar bodies were noted and these when oval measured $c a .4 .8 \times 12 \mu \mathrm{m}$ or when round $9.6 \times 9.6 \mu \mathrm{m}$ in diameter. Again they could be seen until a late stage in development. At $10-12{ }^{\circ} \mathrm{C}$ the developmental period was about 16 days, at room temperature $\left(18-22{ }^{\circ} \mathrm{C}\right)$ 9-10 days.

Changes in capsular size and volume (Table 2)

The ratio between the egg-capsule volume and the egg volume itself was $2 \cdot 1(1 \cdot 8-2 \cdot 4)$. The capsule volume showed no increase until the earliest signs of veliger development 
and the first appearances of minute velar cilias. As in the other two species, there is a certain variation of capsule size within each spawn. As the veliger grows and starts to rotate there is a marked increase in capsule volume which is maintained until the hatching stage is reached. The ratio between the capsule volume at hatching and that of the original egg-capsule volume (enlargement factor) was $3 \cdot 4(2 \cdot 9-4 \cdot 1)$. The ratio between the capsule length and width at the beginning of development was 1.3 and at the time of hatching $1 \cdot 1$, and again the shape of the capsule became more spherical. The newly hatched veliger is type I (Thompson, 1961), the average shell measuring $160 \mu \mathrm{m}$ [134-172] in length, $124 \mu \mathrm{m}$ [110-137] in width and $123 \mu \mathrm{m}$ [100.8-134] in height.

\section{Comment}

Miller (1958) describes the egg colour as white or pink, as found in our case. No further data are available on egg diameter or time of development.

\section{Doto fragilis}

The spawning animals measured between 18 and $28 \mathrm{~mm}$ (Pl. IC). Spawns used were found in the Plymouth area on Nemertesia antennularia only, together with the animal concerned, or were those laid down by animals after they had been brought into the laboratory. The spawn consists of a band of tightly packed windings, measuring up to $3.5 \mathrm{~cm}$ in length (unstraightened), the band itself being up to $5 \mathrm{~mm}$ in width (Pl. IIC). Again, at the end of the band empty capsules could be found. The eggs themselves were white. In all nine spawns were measured, four from oviposition to hatching, the remaining five for different lengths of time during development.

The egg capsules have a smooth surface and contain one, sometimes two eggs per capsule (PI. IIIA). Some spawns show no twins at all, others have up to $50 \%$. Sections of a spawn may show a prevalence of twin ova. The average egg diameter is $83 \mu \mathrm{m}$ $(76 \cdot 8-86 \cdot 4)$. As a rule 1-3 polar bodies were noted, oval or round in shape and of an average diameter $7.2 \times 9.6 \mu \mathrm{m}$. They were still recognizable shortly before hatching. At $10-12{ }^{\circ} \mathrm{C}$ the developmental period was about 18 days, at room temperature $\left(18-22^{\circ}\right)$ 9-10 days.

\section{Changes in capsular size and volume (Table 3)}

The ratio between the egg-capsule volume and the egg volume itself is $2 \cdot 4(2 \cdot 0-2 \cdot 6)$. There is no change in capsule volume up to the gastrula stage, then a slight increase can be noticed until the first signs of veliger development. The marked increase of capsule volume, however, starts at the same early veliger stage as in the other two species described. The enlargement factor (ratio between volume of the capsule at hatching time and egg-capsule volume) is $3.8(3.4-4 \cdot 3)$. The ratio between the capsule length and width after oviposition is $1 \cdot 3$, at hatching time $1 \cdot 1$, i.e. the capsules show the same tendency to become more spherical as in the other two species described. The newly hatched veliger is type I. The average shell measuring $145 \mu \mathrm{m}$ [134-158] in length, $111 \mu \mathrm{m}[106-120]$ in width and $113 \mu \mathrm{m}$ [106-120] in height (Pl. IIIF, G). 
TABLE 3. DOTO FRAGILIS: MEAN VALUES OF EGG AND CAPSULE SIZES AND VOLUMES

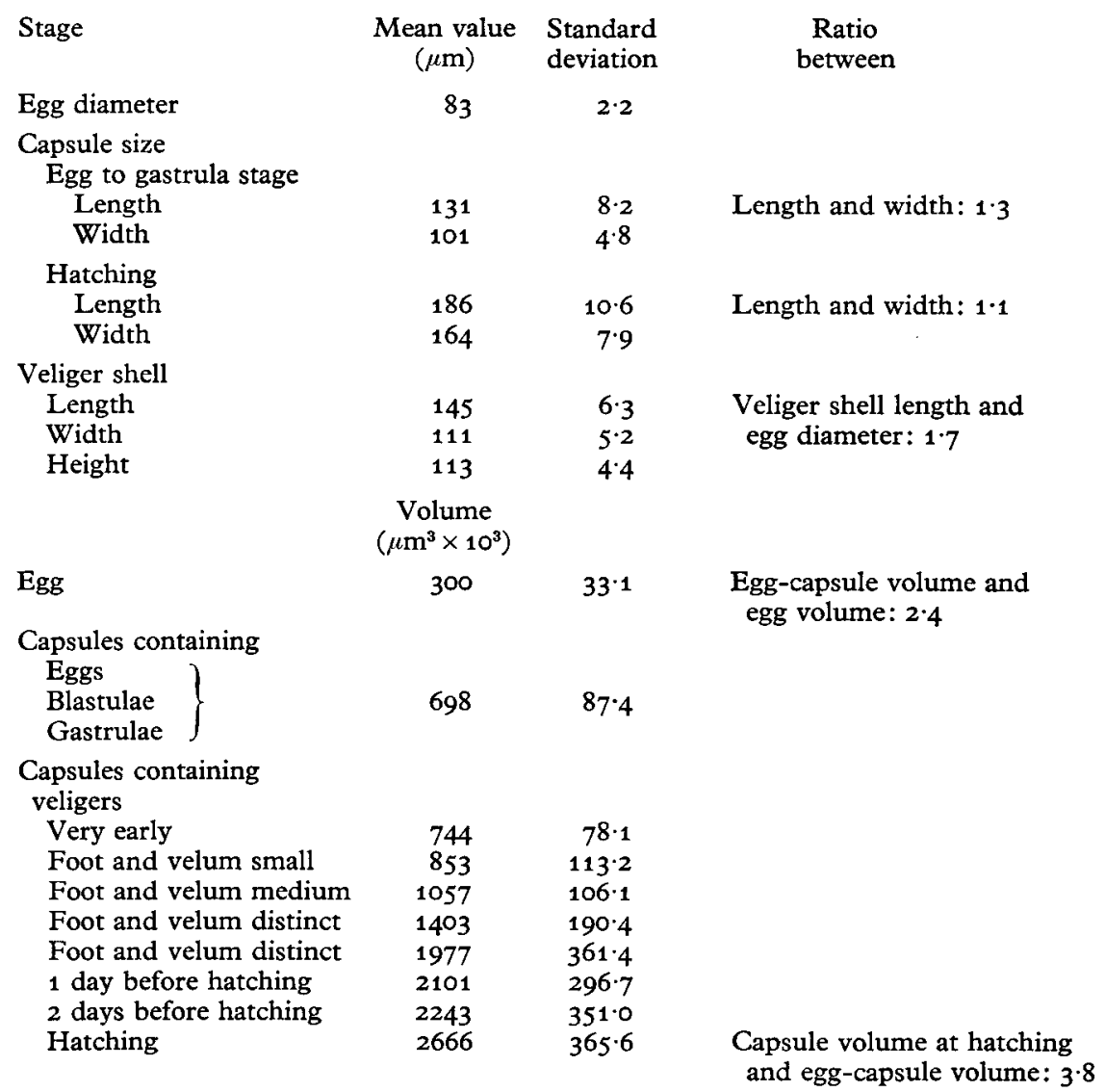

\section{Comment}

One typical way of laying down their spawn is shown in Alder \& Hancock (1845-55). Our measurements of egg diameters are within the range of those measured by Miller (1958) of $70-87 \mu \mathrm{m}$. He observed pink-coloured eggs as well as white ones. We have never found a pink $D$. fragilis spawn.

\section{Salinity tests}

The observed changes in capsule volume in Doto as well as in other nudibranchs (Kress, 1971, 1972), and interest in possible factors responsible for this phenomenon, led us to study the capsule behaviour in different salinities. Only a few preliminary tests have been performed to narrow the possible field for further experiments, but nevertheless some interesting results emerged. The sea-water salinity measured for rearing the veligers under normal conditions was $35.0 \%$.

Blastula stages put into jars with differently diluted sea water for further development showed some striking differences between various species of opisthobranchs. Both the species tested, $D$. coronata and $D$. fragilis, reacted in the same way. Even small changes 
proved damaging (Table 4). Placida dendritica developed normally and without delay even in sea water of only $26.25 \%$ salinity. In no case was any increase in capsule volume found which exceeded the normally measured volume as shown in Hagerman's paper (1970) for Elysia viridis.

TABLE 4. EFFECT OF SALINITY ON EMBRYONIC DEVELOPMENT

\begin{tabular}{cl} 
Salinity & \multicolumn{1}{c}{ Results } \\
$24.5 \%$ (diluted $33 \%$ ) & All embryos dead within $48 \mathrm{~h}$ \\
$26.25 \%$ (diluted $25 \%$ ) & $\begin{array}{l}\text { A few embryos reach a very early veliger stage } \\
\text { at the time when normally kept animals hatch }\end{array}$ \\
$31.5 \%$ (diluted $10 \%$ ) & $\begin{array}{l}\text { Two out of 10 embryos hatched with } 2 \text { days delay } \\
\text { compared with normally kept animals. The others } \\
\text { are retarded or died at different stages of } \\
\text { development }\end{array}$ \\
$33.25 \%$ (diluted $5 \%$ ) & $\begin{array}{l}\text { Seven out of } 10 \text { embryos hatched with a delay of } \\
\text { 2 days }\end{array}$
\end{tabular}

TABLE 5. COMPARATIVE EMBRYOLOGICAL DATA OF D. CORONATA, D. PINNATIFIDA AND D. FRAGILIS

Mean values of diameters, volumes and different ratios

Doto coronata Doto pinnatifida Doto fragilis

Egg diameter $(\mu \mathrm{m})$

Egg volume $\left(\mu \mathrm{m}^{3} \times^{3}\right)$

Ratio: egg-capsule volume/egg volume

Ratio: capsule length/width (egg-capsule)

Ratio: capsule length/width (hatching stage)

Ratio: length capsule (hatching stage)/length egg capsule

Ratio: volume capsule at hatching/egg-capsule volume $=$ enlargement factor

Capsule volume at hatching $\left(\mu \mathrm{m}^{3} \times 10^{3}\right)$

Veliger shell $(\mu \mathrm{m})$

Length

Width

Height

Ratio: veliger shell width/height

Ratio: veliger shell length/width or height

Ratio: length of capsule at hatching/veliger shell

length

Ratio: veliger shell length/egg diameter

Development time $\left(10-12{ }^{\circ} \mathrm{C}\right)$ in days

$\begin{array}{lll}72 \cdot 5 \mu \mathrm{m} & 95 \cdot 5 \mu \mathrm{m} & 83 \mu \mathrm{m} \\ 198 & 455 & 300 \\ 1 \cdot 9(1 \cdot 6-3 \cdot 0) & 2 \cdot 1(1 \cdot 8-2 \cdot 4) & 2 \cdot 4[(2 \cdot 0-2 \cdot 6) \\ 1 \cdot 3 & 1 \cdot 3 & 1 \cdot 3 \\ 1 \cdot 1 & 1 \cdot 1 & 1 \cdot 1 \\ 1 \cdot 4 & 1 \cdot 4 & 1 \cdot 4 \\ & & \\ 3 \cdot 5(3 \cdot 1-4 \cdot 0) & 3 \cdot 4(2 \cdot 9-4 \cdot 1) & 3 \cdot 8(3 \cdot 4-4 \cdot 3) \\ 1312 & 3202 & 2666 \\ 116 & 160 & 145 \\ 95 & 124 & 111 \\ 95 & 123 & 113 \\ 1 & 1 & 1 \\ 1 \cdot 2 & 1 \cdot 3 & 1 \cdot 3 \\ 1 \cdot 2 & 1 \cdot 2 & 1 \cdot 3 \\ & & \\ 1 \cdot 6 & 1 \cdot 7 & 1 \cdot 7 \\ 13 & 16 & 18\end{array}$

\section{DISCUSSION}

The summarized facts of egg-capsule changes during development of the embryo in Text-fig. 2 exhibit distinct differences within the three species after oviposition as well as at hatching time, thus the specific increase characteristics are almost the same. Table 5 on the other hand shows that in spite of the above-mentioned differences in size and volume of capsule and egg itself, the ratio of some of the features is very similar if not identical in all three species. This holds true for the ratio capsule length/capsule at hatching stage, or the ratio length of the capsule after oviposition/length at hatching. The ratio egg-capsule volume/egg volume appears different in the given mean size, but there is considerable overlapping. The enlargement factor itself is very similar and varies 


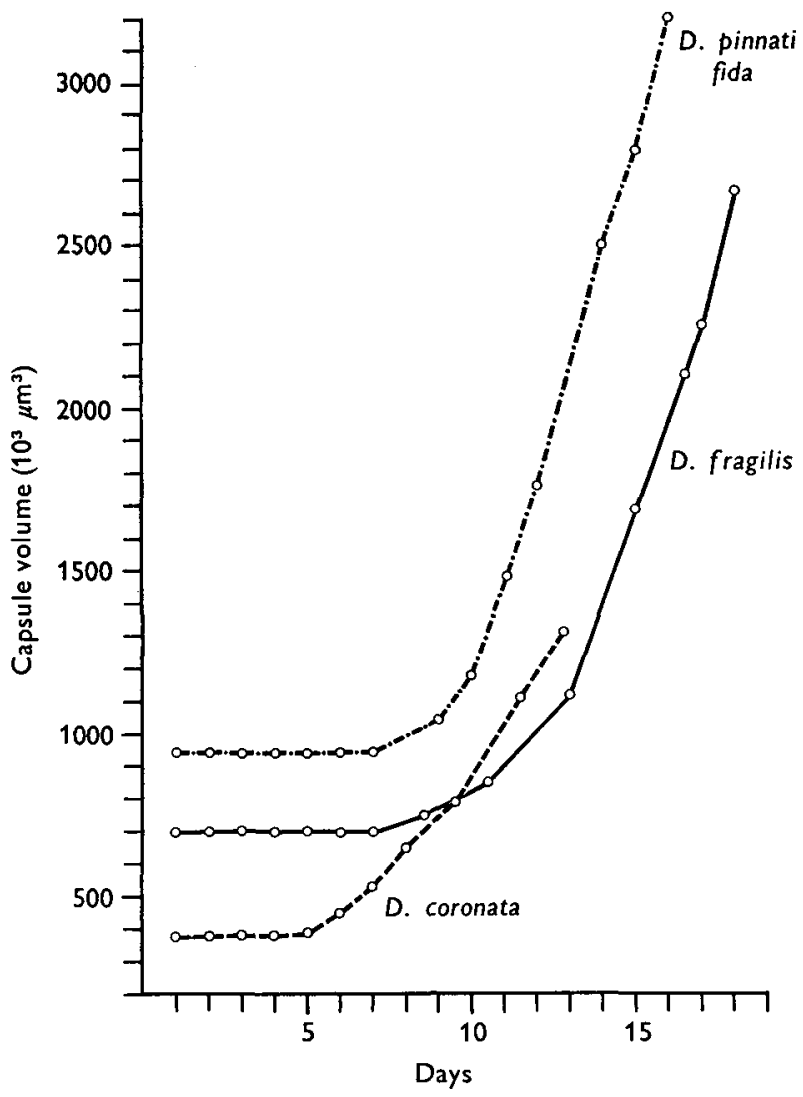

Text-fig. 2. Mean values of capsule volumes during development of the three Doto species.

practically within the same range for all three species. The shell sizes of the newly hatched veligers are, however, distinctly different. The shell sizes display the expected relation to the egg diameter. The species with the smallest egg diameter, $D$. coronata, produces the smallest veliger, $D$. pinnatifida the largest, the ratio between veliger shell length and egg diameter being in all three cases 1.6 or 1.7 respectively. The proportions of the veliger shells themselves are practically identical. The sizes of capsules are more uniform and the development is much more synchronous at the beginning of embryogenesis and show much greater differences nearer to the time of hatching, in the embryo itself as well as in capsule volume. The latter is clearly expressed in the greater standard deviation given in Tables 1,2 and 3.

After hatching the larvae swim upwards (first obligatory phase) and get caught in the water-surface film as described by Thompson (1958). Experiments aimed at obtaining larval settlement have so far proved unsuccessful and nothing is known about the duration of planktonic life. Because it was not possible to follow the entire life cycle, examination of any differences in egg or capsule sizes of first or later spawns laid by the same animal could not be carried out. Data from other species of the suborder Dendronotoidea are so scarce that no comparison within this group is at present possible. 
I wish to thank the Director of the Laboratory, Plymouth, for providing facilities during summer 1971 and 1974; Miss L. Serpell for her help with the English manuscript, and Mr H. J. Stöcklin for his capable assistance with the photographs.

\section{REFERENCES}

Alder, J. \& Hancock, A., 1845-1855. A monograph of the British Nudibranchiate Mollusca. $43^{8}$ pp. London: Ray Society.

Hadfield, M. G., 1963. The biology of nudibranch larvae. Oikos, 14, 85-95.

HAGERMAN, L., 1970. The influence of low salinity on survival and spawning of Elysia viridis (Montagu) (Opisthobranchia, Sacoglossa). Sarsia, 42, 1-6.

KRESS, A., 1971. Ueber die Entwicklung der Eikapselvolumina bei verschiedenen Opisthobranchier-Arten (Mollusca, Gastropoda). Helgoländer wissenschaftliche Meeresuntersuchungen, 22, 326-349.

KRESS, A., 1972. Veränderungen der Eikapselvolumina während der Entwicklung verschiedener Opisthobranchier-Arten (Mollusca, Gastropoda). Marine Biology, 16, 236-52.

LarSEN, M., 1925. Nudibranchfaunaen. I, Drøbaksundet. II, Holo- og Cladohepatica. Skrifter utgitt av det Norske videnskaps-akademi i Oslo. I. Matematisk-Naturvidenskapelig Klasse, no. 2, 5-60.

LðYNING, P., 1927. Nudibranchs from Bergen, collected in the neighbourhood of the Biological Station at Herdla. Nytt magasin for naturvidenskapene, 65, 243-64.

Mirler, M., 1958. Studies on the Nudibranchiate Mollusca of the Isle of Man. Ph.D. Thesis, University of Liverpool.

Pelseneer, P., 1911. Recherches sur l'embryologie des Gastropodes. Mémoires de l'Académie royale de Belgique, 3, 1-167.

SCHMEKel, L. \& KRESS, A. Die Gattung Doto (Gastropoda, Nudibranchia) im Mittelmeer und im Aermelkanal mit Beschreibung einer neuen Art, Doto acuta n. sp. (In the Press.)

Thompson, T. E., 1958. The natural history, embryology, larval biology and post-larval development of Adalaria proxima (Alder and Hancock) (Gastropoda, Opisthobranchia). Philosophical Transactions of the Royal Society, B, 242, 1-58.

Thompson, T. E., 1961. The importance of the larval shell in the classification of the Sacoglossa and the Acoela (Gastropoda, Opisthobranchia). Proceedings of the Malacological Society of London, 34, 233-8.

Thompson, T. E., 1967. Direct development in a nudibranch, Cadlina laevis, with a discussion of developmental processes in Opisthobranchia. Fournal of the Marine Biological Association of the United Kingdom, 47, 1-22.

\section{EXPLANATION OF PLATES}

\section{Plate I}

A, Doto coronata, $10 \mathrm{~mm}$; B, Doto pinnatifida, $20 \mathrm{~mm}$; c, Doto fragilis, $22 \mathrm{~mm}$.

\section{Plate I I}

A. Doto coronata, spawn, length $10 \mathrm{~mm}$.

B. Doto pinnatifida, spawn, length $22 \mathrm{~mm}$.

C. Doto fragilis, spawn, length $28 \mathrm{~mm}$.

D. Egg in egg-capsule immediate lyafter oviposition and prior to extrusion of polar body (D. fragilis). ( $\times 167)$

E. Egg during formation of the first polar body (D. fragilis). ( $\times 167)$

F. Blastula with two polar bodies (D. fragilis). $(\times 167)$

G. Gastrula (D. pinnatifida). $(\times 167)$

H. After gastrulation, beginning of the formation of a very early veliger (D. fragilis).$(\times 167)$

I. Very early veliger, first signs of cilia. ( $\times 167)$ 

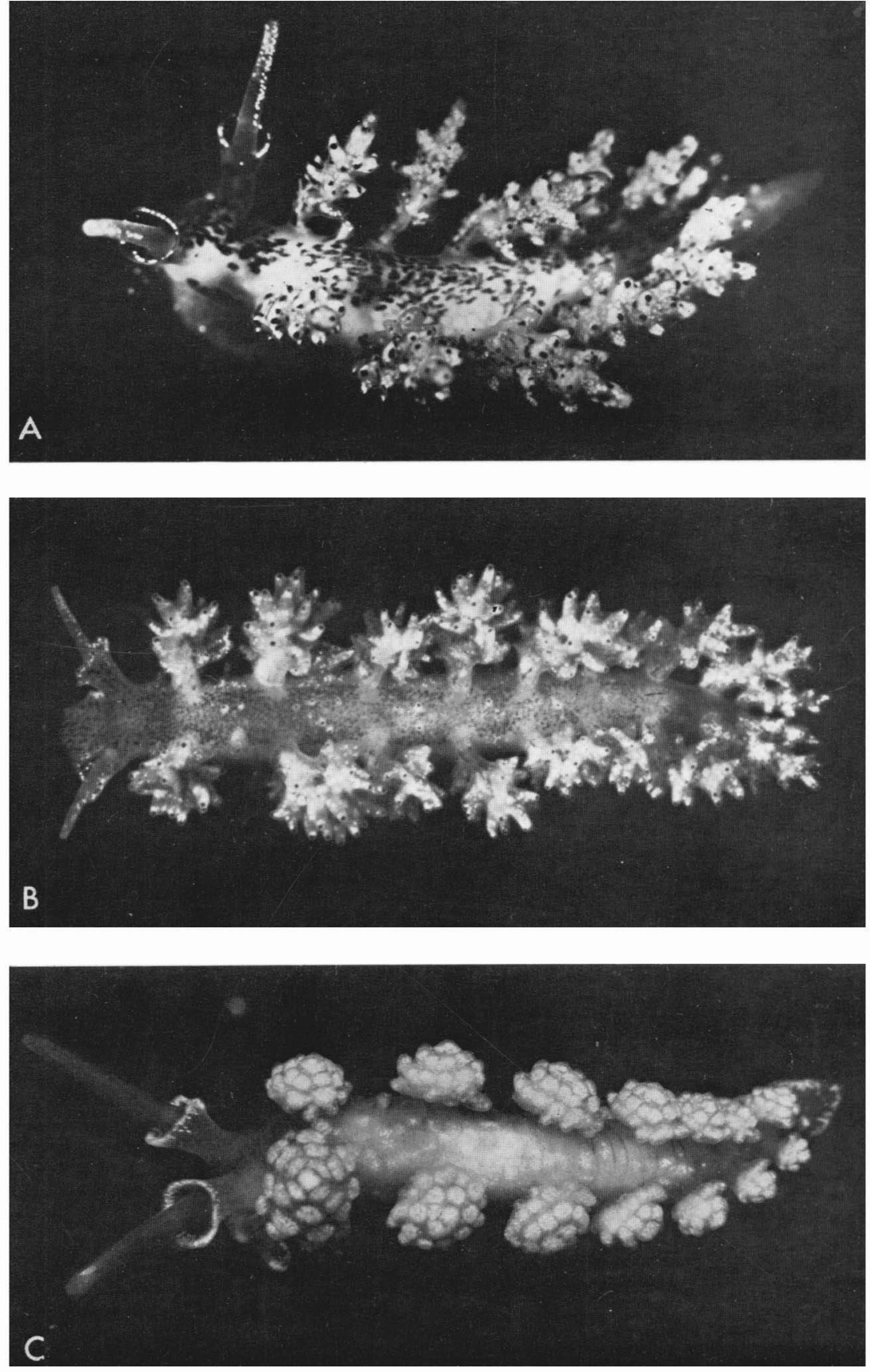

(Facing p. 700) 

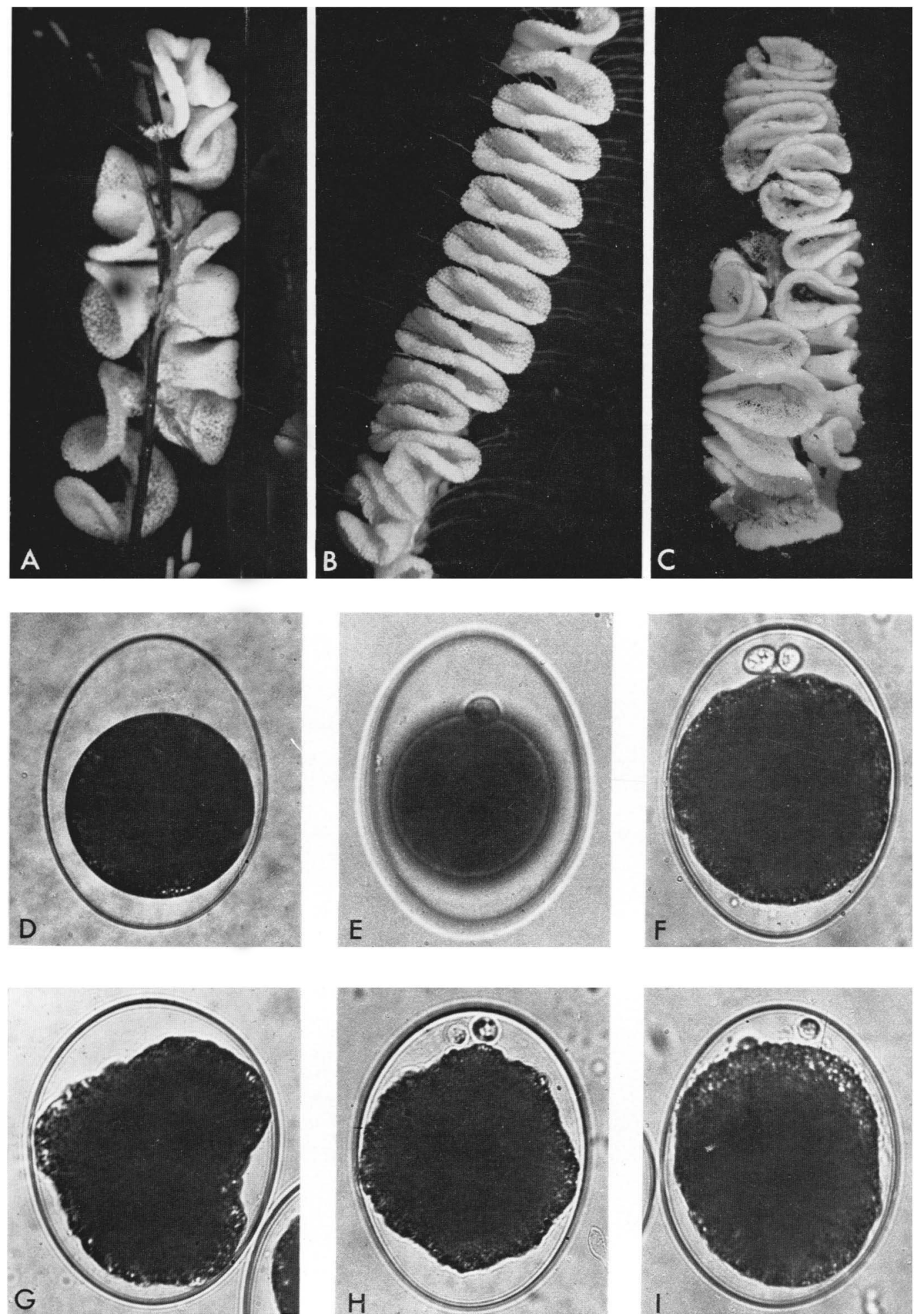

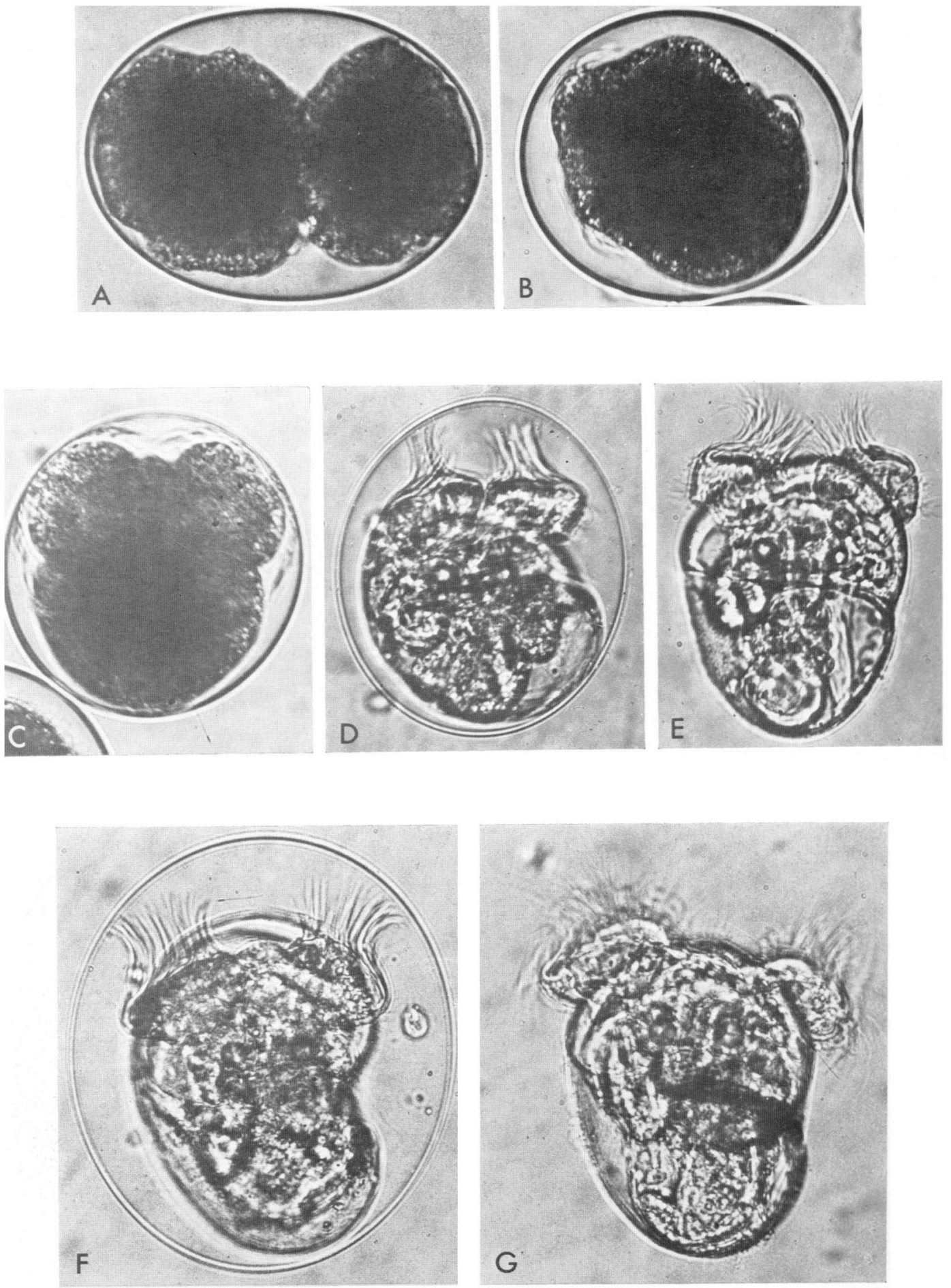


\section{Plate II I}

(Magnification $\times 167$ )

A. Twin-formation, very early veliger (D. fragilis).

B. Small veliger, first signs of foot and velum (D. pinnatifida).

C. Young veliger (medium) (D. pinnatifida).

D. Veliger shortly before hatching (D. coronata).

E. Newly hatched veliger (D. coronata).

F. Veliger shortly before hatching (D. fragilis).

G. Newly hatched veliger (D. fragilis). 